\title{
Penggalian Tambang Ilegal yang Terjadi di Kecamatan Sukatani Kabupaten Purwakarta Dihubungkan dengan Peraturan Daerah Kabupaten Purwakarta Nomor 6.A Tahun 2009 Tentang Pengelolaan Pertambangan Umum
}

\author{
Sri Wahyuni ${ }^{1 *}$, H. Uu Idjudin Solihin ${ }^{2}$ \\ ${ }^{1,2}$,Fakultas Hukum, Universitas Singaperbangsa Karawang, Indonesia \\ Jalan HS Ronggowaluyo, Telukjambe Timur, Karawang, Jawabarat 41361 \\ *Correspondence email: sriwww1@gmail.com; oficiumnobile@gmail.com
}

\begin{abstract}
Abstrak. Dalam pengusahaan tambang di Indonesia, setiap pelaku usaha diharuskan mengantongi izin resmi sebelum melaksanakan kegiatan dan/atau Usaha Pertambangan tersebut. Izin ini dapat diperoleh dari pemerintah, karena izin adalah perbuatan pemerintah bersegi satu berdasarkan peraturan perundang-undangan untuk diterapkan pada peristiwa konkret menurut prosedur dan persyaratan tertentu. Namun pada kenyataanya banyak sekali pelaku usaha tambang yang melakukan aktivitas pertambangan tanpa mengantongi izin, sehingga penulis tertarik untuk mengetahui faktor-faktor penyebab terjadinya galian tambang ilegal. Dan metode penelitian yang dilakukan dalam penulisan ini yaitu menggunakan metode yuridis-normatif, dimana teknik pengumpulan datanya diteliti melalui studi kepustakaan, buku-buku hukum, serta literatur lainnya. Selain itu juga penulis menggunakan data primer, yaitu dengan melakukan wawancara bersama pihak yang mengetahui kasus galian tambang ilegal tersebut. Faktor yang menyebabkan terjadinya penggalian tambang ilegal di Kecamatan Sukatani Kabupaten Purwakarta yaitu karena adanya permintaan penggalian tanah untuk proyek nasional Jalan Tol Jakarta - Cikampek, sehingga proyek ini dijadikan alasan pembenaran oleh pengusaha tambang dalam melakukan kegiatan pertambangan tanpa memiliki izin resmi dari pemerintah.
\end{abstract}

Kata Kunci: Tambang Ilegal; Izin; Purwakarta

Abstract. In mining exploitation in Indonesia, every business actor is required to have a Mining Business License prior to carrying out such mining activities and / or businesses. This permit can be obtained from the government, because a permit is a one-sided government act based on statutory regulations to be applied to concrete events according to certain procedures and conditions. However, in fact there are many mining business actors who carry out mining activities without obtaining a permit, so the author is interested in knowing the factors that cause illegal mining to occur. And the research method used in this writing is using the juridical-normative method, where the data collection techniques are researched through literature studies, law books, and other literature. In addition, the authors also use primary data, namely by conducting interviews with parties who are aware of the illegal mining case. The factor that led to illegal mining excavation in Sukatani Subdistrict, Purwakarta Regency, was the demand for a national project for the Jakarta - Cikampek Toll Road, so this project was used as a justification for mining entrepreneurs to carry out mining activities without having an official permit from the government.

Keywords: Illegal Mining; Permit; Purwakarta

\section{PENDAHULUAN}

Indonesia adalah salah satu negara kesatuan yang memiliki kekayaan sumber daya alam yang cukup banyak, salah satunya kaya akan bahan tambang yang melimpah. Hal ini disebabkan karena wilayah Indonesia terletak di antara dua lempeng besar, yaitu lempeng Eurasia dan Fasifik. Akibatnya banyak terjadi tumbukan lempeng disini, sehingga membuat kandungan minyak bumi, gas, dan logam-logam sangat berlimpah di dalamnya.

Pertambangan adalah sebagian atau seluruh tahapan kegiatan dalam rangka, pengelolaan dan pengusahaan mineral atau batubara yang meliputi penyelidikan umum, eksplorasi, studi kelayakan, konstruksi, penambangan, pengolahan dan/atau pemurnian atau pengembangan dan/atau pemanfaatan, pengangkutan dan penjualan, serta kegiatan pascatambang. ${ }^{1}$ Sedangkan Usaha Pertambangan merupakan kegiatan dalam rangka pengusahaan bahanbahan tambang yaitu mineral dan batubara, dengan meliputi banyak tahapan-tahapan serta kegiatan pascatambang.

Dalam pengusahaan tambang di Indonesia, setiap pelaku usaha diharuskan memiliki Izin Usaha Pertambangan sebelum melakukan kegiatan dan/atau Usaha Pertambangan tersebut. Izin ini dapat diperoleh dari pemerintah, karena izin adalah perbuatan pemerintah bersegi satu berdasarkan peraturan perundang-undangan untuk diterapkan pada peristiwa konkret menurut prosedur dan persyaratan tertentu. ${ }^{2}$ Dan perbuatan pemerintah ini merupakan tindakan

1 Undang-Undang Nomor 3 Tahun 2020 tentang Perubahan atas Undang-Undang Nomor 4 Tahun 2009 tentang Pertambangan Mineral dan Batubara.

${ }^{2}$ Ridwan HR, Hukum Administrasi Negara, PT Raja Grafindo Persada, Jakarta, 2018, hlm. 201. 
Sri Wahyuni dan H. Uu Idjudin Solihin, Penggalian Tambang Ilegal yang Terjadi di Kecamatan Sukatani Kabupaten Purwakarta Dihubungkan dengan Peraturan Daerah Kabupaten Purwakarta Nomor 6.A Tahun 2009 Tentang Pengelolaan Pertambangan Umum

hukum, yang artinya dalam pembuatan dan penerbitan keputusan izin harus ada wewenang berdasarkan asas legalitas. Karena jika tidak ada dasar wewenang,, maka tindakan hukum itu menjadi tidak sah.

Dalam hal ini artinya segala kegiatan dan/atau usaha pertambangan di Indonesia wajib memiliki perizinan sebelum beroperasi. Tapi pada kenyataannya masih banyak pelaku usaha khususnya dalam kegiatan dan/atau usaha pertambangan yang tidak memiliki izin atau perizinannya belum selesai, akan teatapi sudah beroperasi. Fenomena ini dapat dikatakan sebagai penggalian tambang ilegal, karena dengan tidak dan/atau belum terbitnya Izin Usaha Pertambangan dari pemerintah, artinya pelaku usaha ini belum memiliki legalitas untuk melaksanakan kegiatan dan/atau usaha pertambangan di wilayah tersebut. Dan hal ini banyak berdampak buruk bagi lingkungan masyarakat yang berada dalam wilayah usaha pertambangan tersebut.

Dampak buruk yang sering terjadi ialah, disamping pelaku usaha dalam melaksanakan kegiatan dan/atau usaha pertambangan yang belum memiliki izin usaha pertambangan ini, mereka juga melakukan eksploitasi alam yang berlebihan. Misalnya dengan melanggar kentuan-ketentuan yang telah ditetapkan pemerintah, salah satunya dengan melanggar batasan-batasan wilayah yang diperbolehkan untuk eksplorasi.

Kejadian seperti ini banyak terjadi dalam kegiatan usaha pertambangan bahan galian golongan $\mathrm{C}$, sebab itu banyak terjadi kerusakan lingkungan contohnya tanah longsor. Sehingga sangat merugikan masyarakat yang terkena dampaknya. Dan kasus seperti ini penulis temukan di Kecamatan Sukatani Kabupaten Purwakarta.

Dalam kasus yang terjadi di Kecamatan Sukatani Kabupaten Purwakarta, penulis memperoleh informasi dari salah satu website media online yang menyebutkan bahwa ada lima proyek galian tambang golongan $\mathrm{C}$ yang tidak memiliki izin dari Dinas Energi dan Sumber Daya Mineral (ESDM) Jawabarat. Sehingga Kepala Dinas Energi dan Sumber Daya Mineral (ESDM) Jawabarat, Bambang Tirtoyuliono memanggil lima pihak yang bersangkutan melalui cabang Dinas Energi dan Sumber Daya Mineral (ESDM) yang ada di Kabupaten Purwakarta.

Setelah sebelumnya kegiatan tersebut diberhentikan sementara agar para pihak menyelesaikan perizinannya terlebih dahulu, tiga diantaranya kembali beroperasi tanpa melakukan proses perizinan. Akhirnya Kepala Dinas Energi dan Sumber Daya Mineral (ESDM) Jawabarat menegaskan bahwa proyek yang tidak mengantongi izin dilarang beroperasi. $^{3}$

\section{METODE \\ Pendekatan Penelitian}

Metode yang digunakan dalam penulisan ini yaitu yuridis-normatif. Dalam penelitiannya dilakukan dengan cara studi kepustakaan buku-buku hukum, Peraturan Perundang-undangan, dan literatur beserta referensi lainnya.

\section{Spesifikasi Penelitian}

Dalam memproleh data serta informasi pada penelitian ini, maka penulis menggunakan metode deskriptif analisis. metode ini dilakukan dengan cara mendeskripsikan atau memberikan gambaran terkait objek yang akan diteliti melalui data-data yang sudah terkumpul.

\section{Jenis dan Sumber Data}

Data yang diambil dalam penulisan ini yaitu dengan menggunakan data sekunder, yaitu dengan melakukan studi kepustakaan, memepelajari peraturan-perundang-undangan, wawancara, serta referensi literatur lainnya.

\section{HASIL DAN PEMBAHASAN}

\section{Faktor penyebab terjadinya penggalian tambang ilegal di Kecamatan Sukatani Kabupaten Purwakarta}

Pertambangan Ilegal merupakan kegiatan penambangan atau penggalian yang dilakukan oleh masyarakat atau perusahaan tanpa adanya izin dari pemerintah serta tidak menggunakan prinsip - prinsip penambangan yang baik dan benar. Pertambangan Ilegal, lebih tepatnya penggalian ilegal pada umumnya dilakukan oleh masyarakat dengan peralatan yang sederhana, tidak berizin, tidak berwawasan lingkungan dan keselamatan serta melibatkan pemodal dan pedagang. Pada kasus tertentu, terdapat juga pertambangan ilegal yang dilakukan oleh perusahaan.

Pertambangan Ilegal yang dilakukan oleh perusahaan biasanya perusahaan tersebut belum memiliki Izin Usaha Pertambangan yang diterbitkan oleh pemerintah, akan tetapi perusahaan tersebut sudah beroperasi melakukan kegiatan dan/atau usaha pertambangannya. seperti hal nya kasus penggalian tambang ilegal yang terjadi dikabupaten purwakarta.

Didalam Pasal 8 ayat (1) dan (2) Peraturan Daerah Kabupaten Purwakarta Nomor 6.A Tahun 2009 tentang Pengelolaan Pertambangan Umum, menyebutkan bahwa "Pelaksanaan Usaha Pertambangan wajib memiliki Ijin

3 https://jabar.tribunnews.com/2020/06/15/galian-tanah-ilegal-di-purwakarta-beroperasi-lagi-sebelum-dapat-izin-ini-katakadis-esdm-jabar [ diakses pada tanggal 12/02/2021 pukul 18.30 ] 
Sri Wahyuni dan H. Uu Idjudin Solihin, Penggalian Tambang Ilegal yang Terjadi di Kecamatan Sukatani Kabupaten Purwakarta Dihubungkan dengan Peraturan Daerah Kabupaten Purwakarta Nomor 6.A Tahun 2009 Tentang Pengelolaan Pertambangan Umum

Usaha Pertambangan " dan " Usaha Pertambangan dapat dilaksanakan setelah mendapat Ijin Usaha Pertambangan (IUP) dari Bupati ". 4

Berdasarkan peraturan diatas, artinya setiap pelaku usaha yang akan melaksanakan Usaha Pertambangan di Kabupaten Purwakarta wajib memiliki Ijin Usaha Pertambangan. Dan pelaksanaan Usaha Pertambangan di Kabupaten Purwakarta diperbolehkan apabila telah mendapat Ijin Usaha Pertambangan (IUP) dari Bupati. Karena dalam Pasal 65 Undang-Undang Nomor 23 Tahun 2014 tentang Pemerintahan Daerah, menyebutkan bahwa tugas kepala daerah yaitu memimpin pelaksanaan urusan pemerintahan yang menjadi kewenangan daerah berdasarkan ketentuan perundangundangan dan kebijakan yang ditetapkan bersama DPRD. ${ }^{5}$

Dengan ini apabila ada pelaku usaha yang melaksanakan Usaha Pertambangan tanpa mengantongi Ijin Usaha Pertambangan (IUP), dapat diberhentikan sementara oleh Bupati dan/atau Dinas-Dinas terkait sampai proses perizinannya selesai. Dan selama proses perzinan itu belum selesai, maka pelaku usaha tidak diperbolehkan beroperasi dan/atau melaksanakan Usaha Pertambangan di Kabupaten Purwakarta.

Dalam pasal 13 ayat (2) huruf b dan g Peraturan Daerah Kabupaten Purwakarta Nomor 6.A Tahun 2009 tentang Pengelolaan Pertambangan Umum, menyebutkan bahwa Ijin Usaha Pertambangan dapat dicabut dan dinyatakan tidak berlaku lagi apabila "Bertentangan dengan kepentingan umum yang lebih luas dari kelestarian lingkungan hidup " dan "Berdasarkan pertimbangan teknis menimbulkan dampak negatif yang tidak dapat diperkirakan sebelumnya ". 6

Disamping dalam melaksanakan Usaha Pertambangan harus memiliki Ijin Usaha Pertambangan (IUP), pelaku usaha juga harus memperhatikan lingkungan dengan melakukan Analisis Risiko Lingkungan Hidup. Analisis Risiko Lingkungan Hidup wajib dilakukan oleh setiap usaha dan/atau kegiatan yang:

1. Berpotensi menimbulkan dampak penting terhadap lingkungan hidup;

2. Mengancam ekosistem dan kehidupan; serta

3. Mengancam kesehatan dan keselamatan ${ }^{7}$

Karena kasus yang terjadi di Kecamatan Sukatani Kabupaten Purwakarta, selain tidak mengantongi Ijin Usaha Pertambangan (IUP) juga hampir merusak lingkungan. Karena melanggar batasan-batasan wilayah yang tidak diperbolehkan untuk di eksplorasi sehingga mengakibatkan tanah longsor dan satu rumah warga rubuh. ${ }^{8}$ Maka dari itu berdasarkan uraian diatas, sudah jelas bahwa Usaha Pertambangan yang merusak lingkungan dan/atau menimbulkan dampak negatif dapat dicabut Ijin Usaha Pertambangannya.

Berdasarkan hasil wawancara dengan Ajudan Ketua Dewan Perwakilan Rakyat Daerah Kabupaten Purwakarta, menurutnya pada saat beliau hadir di lokasi galian tambang ilegal tersebut ketika Ketua DPRD bersama jajarannya melakukan sidak, faktor-faktor penyebab terjadinya penggalian tambang ilegal yang terjadi di Kecamatan Sukatani Kabupaten Purwakarta yaitu:

\section{Faktor Internal}

Adanya permintaan penggalian tanah untuk proyek nasional, yaitu pengembangan proyek jalan tol Jakarta Cikampek sehingga ini dijadikan alasan pembenaran oleh para pengusaha tambang yang akhirnya mendorong mereka untuk melakukan galian tambang tanpa adanya Izin Usaha Pertambangan dari Pemerintah Daerah. ${ }^{9}$ Pada akhirnya kasus ini terdengar sampai tataran kekuasaan eksekutif maupun legislatif di Kabupaten Purwakarta, sehingga Ketua DPRD Kabupaten Purwakarta beserta jajarannya mengadakan sidak langsung ke lokasi galian tambang ilegal tersebut.

Pada saat itu seluruh pengusaha tambang yang tidak memiliki Izin Usaha Pertambangan diberi peringatan agar memberhentikan sementara kegiatan tersebut sampai terbitnya Izin Usaha Pertambangan dari Pemerintah Daerah. Akan tetapi hal tersebut tidak didengar oleh beberapa pengusaha tambang di Kabupaten Purwakarta, karena ada sekitar lima pengusaha tambang yang masih beroperasi setelah penyidakan oleh penguasa legislatif Kabupaten Purwakarta tersebut. Pada akhirnya kabar tersebut terdengar oleh Bupati Purwakarta, sehingga membuat geram yang akhirnya mengadakan sidak kembali ke lokasi galian tambang ilegal tersebut dan memberi peringatan keras kepada seluruh pengusaha tambang apabila galian tambang ini masih beroperasi tanpa mengantongi izin, maka lokasi galian tambang ini akan ditutup permanen.

\footnotetext{
${ }^{4}$ Pasal 8, Peraturan Daerah Kabupaten Purwakarta Nomor 6.A Tahun 2009 tentang Pengelolaan Pertambangan Umum.

${ }^{5}$ H. Deni Nuryadi, Aktualisasi Otonomi \& Hukum Pemerintahan Daerah, Alqaprint Jatinangor, Sumedang, 2018, hlm. 69.

${ }^{6}$ Pasal 13, Op.Cit.

${ }^{7}$ Muhamad Erwin, Hukum Lingkungan, PT Refika Aditama, Bandung, 2015, hlm. 25.

8 https://jabar.tribunnews.com/2020/06/15/galian-tanah-ilegal-di-purwakarta-beroperasi-lagi-sebelum-dapat-izin-ini-katakadis-esdm-jabar [ diakses pada tanggal 12/02/2021 pukul 18.30 ]

${ }_{9}$ Wawancara dengan Dani Mulyaman selaku Ajudan Ketua Dewan Perwakilan Daerah Kabupaten Purwakarta pada
} tanggal 17 Februari 2021. 
Sri Wahyuni dan H. Uu Idjudin Solihin, Penggalian Tambang Ilegal yang Terjadi di Kecamatan Sukatani Kabupaten Purwakarta Dihubungkan dengan Peraturan Daerah Kabupaten Purwakarta Nomor 6.A Tahun 2009 Tentang Pengelolaan Pertambangan Umum

Hal tersebut selain tidak taat administratif, juga berdampak buruk terhadap lingkungan, karena bukan berarti dengan adanya proyek nasional itu pemerintah daerah harus mengorbankan lahan-lahan di Purwakarta untuk dikeruk tanahnya, karena akan merusak lingkungan dan keseimbangan ekosistem.

\section{Faktor Eksternal}

Tidak adanya kewenangan Kepala Desa setempat untuk mencegah para pengusaha tambang melakukan galian tambang, karena Izin Usaha Pertambangan tidak dikeluarkan oleh Desa, sehingga sangat sulit bagi Kepala Desa untuk mencegah atau menghentikan terjadinya galian tambang tanpa izin di daerahnya. Selain itu juga dipengaruhi oleh faktor ekonomi masyarakat setempat dan ketidaktahuan soal galian tambang tanpa izin. Masyarakat setempat biasanya dijadikan tukang parkir kendaraan keluar masuk, dan mereka hanya tahu bahwa mereka kerja ditempat tersebut untuk mendapatkan upah. ${ }^{10}$

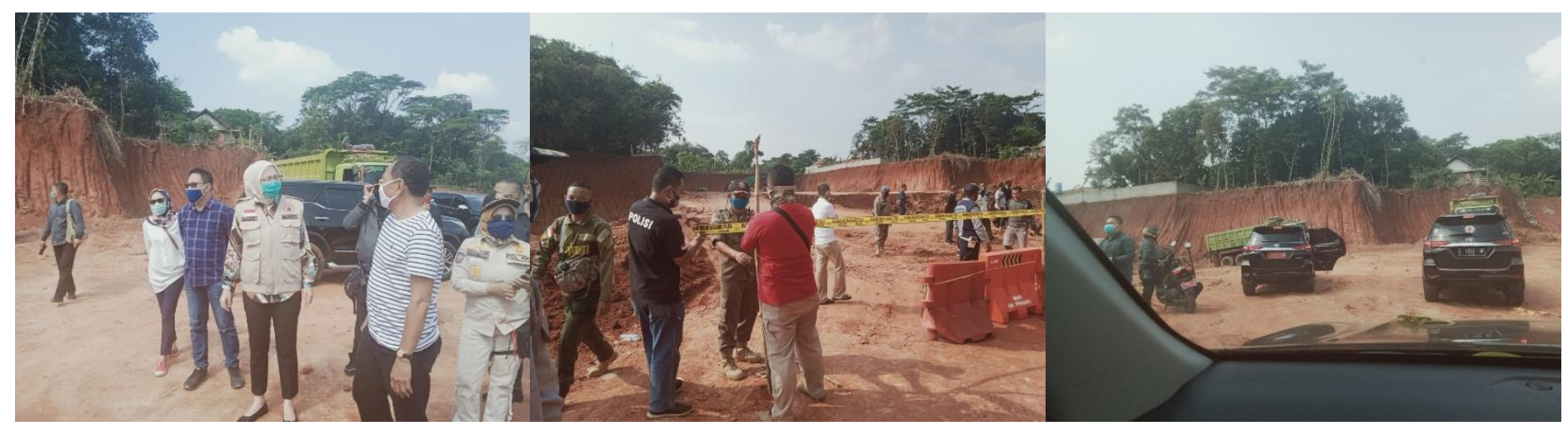

\section{Akibat Hukum Penggalian Tambang Ilegal Berdasarkan Perda Kab. Purwakarta No. 6A Tahun 2009 tentang Pengelolaan Pertambangan Umum}

Sebagaimana yang telah diketahui dalam pasal 8 angka (1) dan (2) bahwa Pelaksana Usaha Petambangan wajib memiliki Ijin Usaha Pertambangan dan Usaha Pertambangan dapat dilaksanakan setelah mendapat Ijin Usaha Petambangan ( IUP ) dari Bupati. Maka dari itu apabila ada Pelaku Usaha Pertambangan yang tidak memiliki izin dan/atau memenuhi ketentuan-ketentuan yang dimaksud dalam pasal 8, Pemerintah Kabupaten Purwakarta Berhak menjatuhkan sanksi-sanksi sebagaimana telah diatur dalam Bab XV tentang Ketentuan Pidana Pasal 31:

(1) Setiap orang melanggar ketentuan-ketentuan sebagaimana diatur dalam pasal 8 diancam pidana kurungan paling lama 6 (enam) bulan atau denda sebanyak-banyaknya Rp. 50.000.000,- ( Lima puluh Juta Rupiah ).

(2) Selain tindak pidana sebagaimana dimaksud pada ayat (1) pasal ini, tindak pidana yang mengakibatkan perusakan dan pencemaran lingkungan dikenakan ancaman pidana sesuai perundang-undangan di bidang lingkungan hidup ${ }^{11}$

Berdasarkan penjelasan diatas maka setiap pelaku usaha yang melakukan pencemaran dan/atau kerusakan lingkungan akan dikenai sanksi pidana undang-undang lainnya. dan apabila terjadi sengketa antara pelaku usaha pertambangan dengan masyarakat, sebagaimana diatur dalam Bab XII tentang Penyelesaian Sengketa Pasal 28 ayat (1) dan (2) "Masalah penyelesaian sengketa yang tidak dapat diselesaikan sebagaimana dimaksud dalam pasal 19 maka akan diselesaikan melalui musyawarah " dan "Apabila para pihak yang bersangkutan tidak menerima penyelesaian sengketa sebagaimana dimaksud dalam ayat (1), maka penyelesaiannya diserahkan kepada Pengadilan Negeri Setempat ". 12

\section{SIMPULAN}

1. Faktor yang menyebabkan terjadinya penggalian tambang ilegal di Kecamatan Sukatani Kabupaten Purwakarta yaitu karena adanya permintaan penggalian tanah untuk proyek nasional Jalan Tol Jakarta - Cikampek, sehingga proyek ini dijadikan alasan pembenaran oleh pengusaha tambang dalam melakukan kegiatan pertambangan tanpa mengantongi izin resmi dari pemerintah dan/atau perizinan usaha pertambangannya belum selesai. Dan faktor lain yaitu ketidaktahuan masyarakat mengenai kegiatan pertambangan ilegal.

\footnotetext{
10 Ibid.

${ }^{11}$ Pasal 31, Peraturan Daerah Kabupaten Purwakarta Nomor 6.A Tahun 2009 tentang Pengelolaan Pertambangan Umum.

12 Ibid, Pasal 28.
} 
Sri Wahyuni dan H. Uu Idjudin Solihin, Penggalian Tambang Ilegal yang Terjadi di Kecamatan Sukatani Kabupaten Purwakarta Dihubungkan dengan Peraturan Daerah Kabupaten Purwakarta Nomor 6.A Tahun 2009 Tentang Pengelolaan Pertambangan Umum

2. Sanksi-sanksi terhadap usaha pertambangan tanpa izin di Kecamatan Sukatani Kabupaten Purwakarta ini telah diatur dalam Pasal 31 Peraturan Daerah Kabupaten Purwakarta Nomor 6.A tahun 2009 tentang Pengelolaan Pertambangan Umum yaitu diancam pidana kurungan paling lama 6 (enam) bulan dan denda sebanyak-banyaknya Rp. 50.000.000,- serta pelanggaran lainnya diatur secara khusus dalam peraturan perundang-undangan terkait.

\section{DAFTAR PUSTAKA}

\section{Buku}

Ridwan HR, Hukum Administrasi Negara, PT Raja Grafindo Persada, Jakarta, 2018.

Muhamad Erwin, Hukum Lingkungan, PT Refika Aditama, Bandung, 2015.

H. Deni Nuryadi, Aktualisasi Otonomi \& Hukum Pemerintahan Daerah, Alqaprint Jatinangor, Sumedang, 2018.

\section{Perundang-undangan}

Undang- Undang Nomor 3 Tahun 2020 tentang Peubahan atas Undang- Undang Nomor 4 Tahun 2009 tentang Pertambangan Mineral dan Batubara.

Undang-Undang Nomor 23 Tahun 2014 tentang Pemerintahan Daerah.

Peraturan Daerah Kabupaten Purwakarta Nomor 6.A Tahun 2009 tentang Pengelolaan Pertambangan Umum.

\section{Internet}

https://jabar.tribunnews.com/2020/06/15/galian-tanah-ilegal-di-purwakarta-beroperasi-lagi-sebelum-dapat-izin-inikata-kadis-esdm-jabar [ diakses pada tanggal 12/02/2021 pukul 18.30 ] 